\title{
Potassium Fertigation to Enhance the Performance of Hypoxis hemerocallidea
}

\author{
Patience Seyram Akakpo and Moosa Mahmood Sedibe \\ Department of Agriculture, Central University of Technology, Free State, \\ Private Bag 6 x20539, Free State, Bloemfontein, 9300, South Africa
}

\section{Bello Zaid}

The Agricultural Research Council, Grain Crops Institute, Private Bag X1251, Potchefstroom, 2520, South Africa

\section{Zenzile P. Khetsha}

Department of Agriculture, Central University of Technology, Free State, Private Bag 6 x20539, Free State, Bloemfontein, 9300, South Africa

\author{
Mokgaputsiwa P. Theka-Kutumela \\ Department of Agriculture and Animal Health, College of Agriculture \\ and Environmental Sciences, University of South Africa, Private Bag X6, \\ Florida 1710, South Africa
}

\section{Fhatuwani N. Mudau \\ Earth and Environmental Sciences, School of Agricultural, University of Kwa-Zulu Natal, Private Bag X01, Scottsville, Pietermaritzburg 3209, South Africa}

Additional index words. African potato, agronomic, medicinal, metabolites, nutrient solution

\begin{abstract}
Potassium (K) is an essential nutrient in plant metabolism, ionic balance, and stress resistance. In this study, the effects of $K$ on agronomic attributes and on mineral and primary metabolite content in African potato were determined. $K$ was administered hydroponically at four concentrations $(4.00,6.00,8.00$, and 10.00 meq $\cdot L^{-1}$ ) using Steiner's universal nutrient solution. Chlorophyll content (CHL), leaf area (LA), fresh corm mass (FCM), number of roots (NR), root fresh weight (RFM), and root dry mass (RDM) were measured 18, 32, and 40 weeks after transplanting. Mineral analysis data were collected at 18 weeks, and primary metabolite data were collected at 32 weeks. Significant effects of $K$ were observed after 18 weeks, and all test concentrations had a positive effect on yield. Calcium and boron significantly accumulated in the corm at $4.00 \mathrm{meq} \cdot \mathrm{L}^{-1} \mathrm{~K}$. Alanine and malic acid were the only metabolites affected by $K$ concentrations. More minerals accumulated in the corm at $4.00 \mathrm{meq} \cdot \mathrm{L}^{-1} \mathrm{~K}$, whereas at $10.00 \mathrm{meq} \cdot \mathrm{L}^{-1} \mathrm{~K}$, more minerals clustered in the leaf. $\mathrm{K}$ applied at $4.00 \mathrm{meq} \cdot \mathrm{L}^{-1}$ is recommended when growing African potato using a nutrient solution to improve corm mineral and metabolite accumulation.
\end{abstract}

Increasing global demand, and the subsequent overexploitation of natural medicinal plant resources calls for the cultivation of medicinal plants to meet growing demands (Chen et al., 2016; Kumar et al., 2016). The African potato (Hypoxis hemerocallidea) is one of the most popular medicinal plants in South Africa, used to treat many diseases. It

Received for publication 26 Aug. 2021. Accepted for publication 4 Oct. 2021.

Published online 23 November 2021

We thank the Central University of Technology, Free State, the National Research Foundation (NRF), South Africa, and the Agricultural Sector Education Training Authority (AgriSETA), South Africa for financial support.

P.S.A. is the corresponding author. E-mail: msedibe@cut.ac.za.

This is an open access article distributed under the CC BY-NC-ND license (https://creativecommons. org/licenses/by-nc-nd/4.0/). is widely harvested from wild populations, without intensive commercial cultivation (Kumar et al., 2016; Mofokeng et al., 2020). Only KwaZulu-Natal Province of South Africa has kept aside 250 ha of land to protect the African potato from overexploitation (Mofokeng et al., 2020). Thus, the domestication of wild plants is critical for sustainable development of this industry.

Fertilizers are used to replenish plants with the essential nutrients required for growth, yield, and quality enhancement (Kalaji et al., 2017; Nyakane et al., 2019). However, fertilizers need to be managed properly to achieve maximum plant production. Nutrient imbalances affect plant growth, yield, and metabolite synthesis due to chemical stress (Ávila-Juárez et al., 2017; Verma and Shukla, 2015). The use of a well-balanced nutrient solution is ideal because it ensures optimal plant production (Mugundhan et al., 2011). Therefore, nutrient solutions are specifically formulated to meet the requirements of specific crops (Ávila-Juárez et al., 2017; Combrink, 2019).

In plants, potassium $(\mathrm{K})$ plays a vital role in metabolism, the cation-anion balance, and stress resistance (Chrysargyris et al., 2017; Hasanuzzaman et al., 2018). However, there is only limited information on the nutrient requirements of the African potato. Therefore, the objective of this study was to determine the effects of $\mathrm{K}$ on agronomic attributes, minerals, and the primary metabolite content in this species. This study will also validate whether cultivated medicinal plants are less potent than their wild counterparts.

\section{Materials and Methods}

Experimental site. The study was carried out in a $72 \mathrm{~m}^{2}(12 \times 6 \mathrm{~m})$ temperature-controlled greenhouse, located at the Central University of technology, Free State campus (lat. $29^{\circ} 07^{\prime} 16.78^{\prime \prime} \mathrm{S}$, long. $26^{\circ} 12^{\prime} 45.95^{\prime \prime} \mathrm{E}$ ). The site is situated in a semiarid region, at $\approx 1395 \mathrm{~m}$ above sea level. The greenhouse temperature was maintained at a constant $26^{\circ} \mathrm{C}$.

Description of the greenhouse facility. The greenhouse was covered using a transparent $200-\mu \mathrm{m}$ polyethylene covering sheet [Gundle Plastics Group (Pty.) Ltd., Gauteng, South Africa]. During the study, because the structure was made of transparent polyethylene sheets, greenhouse day and night temperatures were said to mimic environmental field conditions. The daylength was like the outside conditions because the structure was completely exposed to the outside environment. The temperature sensor was set at $26^{\circ} \mathrm{C}$ to triggers and activates the axial fan to remove hot air within the greenhouse. Relative humidity, maximum and minimum air temperature inside the greenhouse facility were measured with a Vaisala meter. During the study, the greenhouse interior highest temperature was in December with the maximum temperature of $34.50{ }^{\circ} \mathrm{C}$ during the day and minimum temperature of $16.00^{\circ} \mathrm{C}$. The lowest temperature was in July with maximum temperature of $20.20^{\circ} \mathrm{C}$ and minimum temperature of $0.80^{\circ} \mathrm{C}$ at night (Table 1).

Planting, irrigation, and general plant management. African potato plantlets generated from tissue culture were obtained from the Agricultural Research Council of South Africa-Vegetable and Ornamental Plant Institute. The experiment was conducted from 29 Oct. 2018 to 2 Aug. 2019 (plants were grown for nine months). Plants were grown in black 9-L potting bags filled with organic potting media at a 2:1 ratio of pine bark and palm peat. Pine bark support plants growth for more than one growing season without any potential for immobilization of nutrients under greenhouse conditions (Jackson and Wright, 2009). Nutrient solution used to prepare experimental treatments is shown in Table 2 .

A custom-made 110-L growing unit (Fig. 1), consisting of a recirculating nutrient solution was used to fertigate experimental plants. The nutrient solutions were adjusted to $\mathrm{pH} 5.5 \pm 0.1$ by adding $47 \mathrm{~mL} 60 \%$ nitric acid per $1000 \mathrm{~L}$ of 
Table 1. Ambient temperature during 2018 and 2019 growing season.

\begin{tabular}{|c|c|c|c|c|c|}
\hline Months & Avg min. temp $\left({ }^{\circ} \mathrm{C}\right)$ & Avg max. temp $\left({ }^{\circ} \mathrm{C}\right)$ & Avg humidity (\%) & Avg wind speed $(\mathrm{m} / \mathrm{s})$ & Avg pressure (hpa) \\
\hline Oct. 2018 & 10.5 & 28.5 & 32.2 & 2.1 & 864.3 \\
\hline Dec. 2018 & 16.0 & 34.5 & 27.9 & 2.9 & 859.6 \\
\hline Mar. 2019 & 14.9 & 30.6 & 50.5 & 1.8 & 862.1 \\
\hline Apr. 2019 & 10.2 & 24.4 & 69.1 & 1.5 & 863.6 \\
\hline May 2019 & 6.6 & 23.7 & 63.1 & 0.9 & 866.2 \\
\hline Aug. 2019 & 3.8 & 25.3 & 27.7 & 1.7 & 874.8 \\
\hline
\end{tabular}

Table 2. Mineral composition of the nutrient solution used to evaluate the effect of potassium on cultivated African potato.

\begin{tabular}{|c|c|c|c|c|c|c|}
\hline \multicolumn{7}{|c|}{ Macronutrients $\left(\mathrm{meq} \cdot \mathrm{L}^{-1}\right)$} \\
\hline 4.00 & 4.00 & 8.55 & 2.45 & 12.00 & 1.10 & 2.39 \\
\hline 8.00 & 8.00 & 5.44 & 1.56 & 12.00 & 1.10 & 2.39 \\
\hline 10.00 & 10.00 & 3.89 & 1.11 & 12.00 & 1.10 & 2.39 \\
\hline \multicolumn{7}{|c|}{ Micronutrients $\left(\mathrm{mg} \cdot \mathrm{L}^{-1}\right)$} \\
\hline 6.00 & 1.12 & 0.54 & 0.18 & 0.03 & 0.02 & 0.05 \\
\hline 8.00 & 1.12 & 0.54 & 0.18 & 0.03 & 0.02 & 0.05 \\
\hline 10.00 & 1.12 & 0.54 & 0.18 & 0.03 & 0.02 & 0.05 \\
\hline
\end{tabular}

Low potassium applied at $4.00 \mathrm{meq} \cdot \mathrm{L}^{-1} \mathrm{~K}$; standard or control applied at $6.00 \mathrm{meq} \cdot \mathrm{L}^{-1} \mathrm{~K}$; high potassium applied at $8.00 \mathrm{meq} \cdot \mathrm{L}^{-1} \mathrm{~K}$; and very high potassium applied at $10.00 \mathrm{meq} \cdot \mathrm{L}^{-1}$.

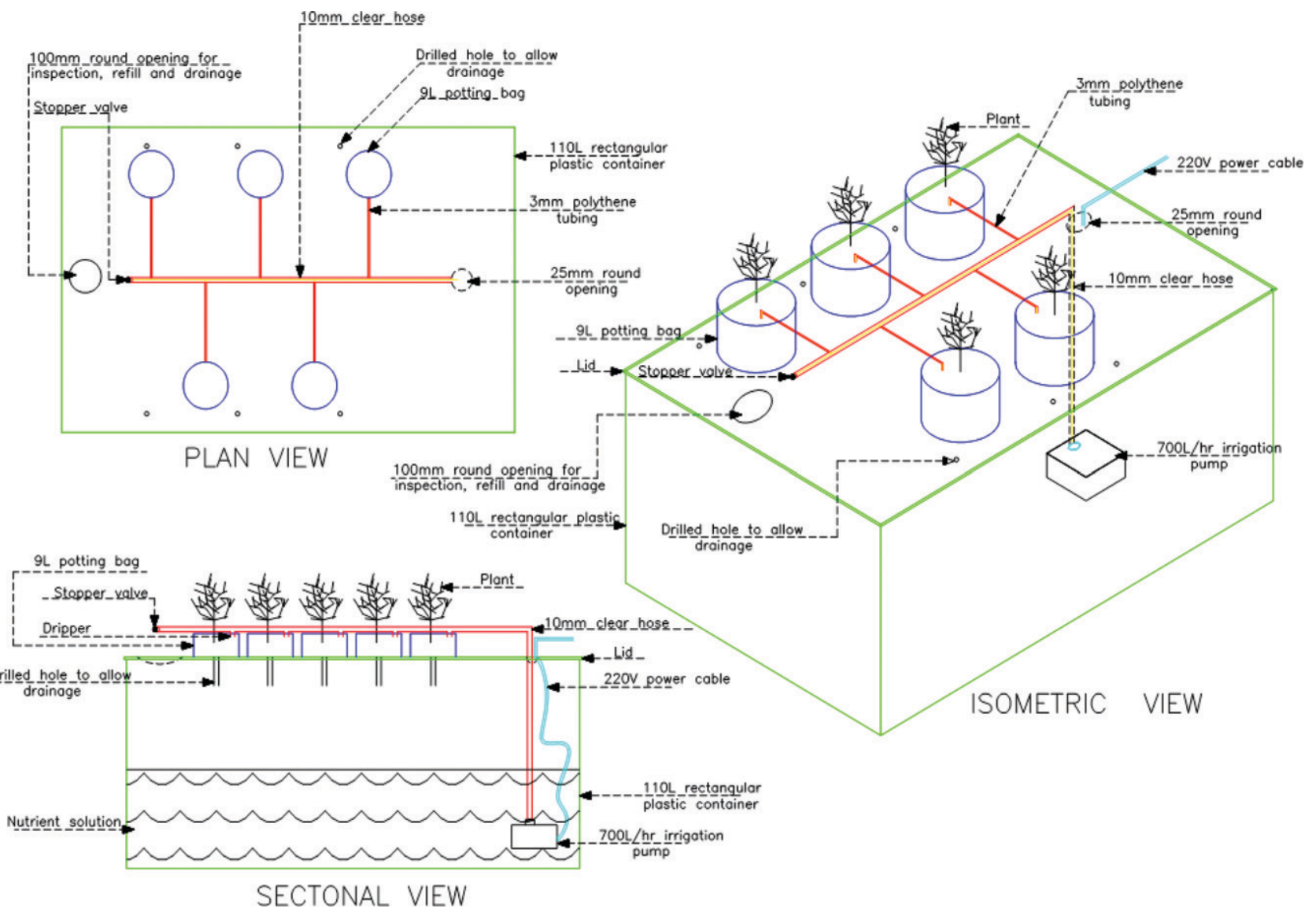

Fig. 1. Schematic representation of the growing unit and irrigation system used to grow African potato plants using potassium concentrations (4.00, 6.00 , 8.00 , and $\left.10 \mathrm{meq} \cdot \mathrm{L}^{-1}\right)$. 


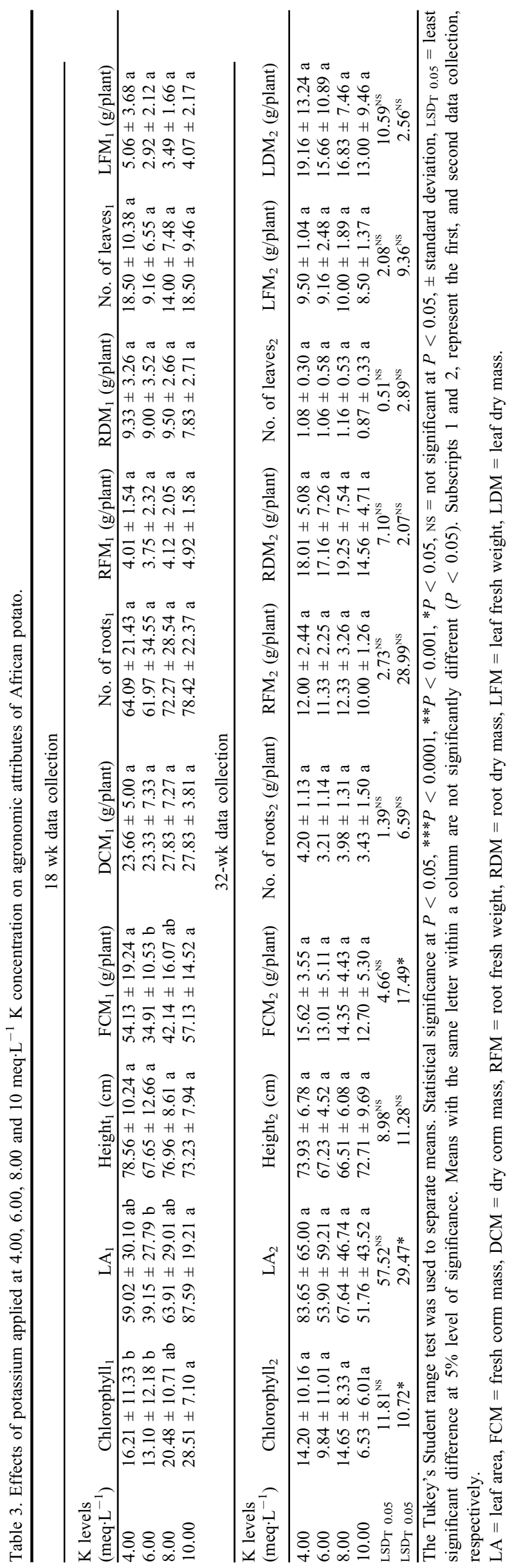

HortScience Vol. 56(12) December 2021 water to lower $\mathrm{HCO}_{3}{ }^{-}$to $0.40 \mathrm{meq} \cdot \mathrm{L}^{-1}$ and $\mathrm{EC}$ was kept at $1.62 \pm 0.01 \mathrm{mS} \cdot \mathrm{cm}^{-1}$ (Combrink, 2019). Each growing unit had an irrigation pump with a $700 \mathrm{~L} \cdot \mathrm{h}^{-1}$ flow rate capacity.

Irrigation was scheduled and adjusted according to the age of plants, season, and the moisture content of the growing media (Mofokeng et al., 2020). Accumulation of salts in the growth media was minimized by applying large volumes of nutrient solution (3-h irrigation) in each irrigation cycle to ensure $10 \%$ to $15 \%$ leaching (Nyakane et al., 2019). Nutrient solutions were replaced with fresh solution once a month to avoid nutrient imbalances (Khetsha and Sedibe, 2015). Micronutrients used in all experimental treatments were prescribed by Combrink (2019).

Experimental design. Four levels of $\mathrm{K}$ were evaluated: $4.00,6.00,8.00$, and 10.00 meq $\mathrm{L}^{-1}$, arranged in a randomized complete block design with six replications. Each experimental unit had five potted plants. Levels of $\mathrm{K}$ and the anions and cations used in this study are shown in Table 2. Agronomic attribute data collection was taken at three time points: 18,32 , and 40 weeks.

Agronomic attributes. Chlorophyll content (CHL), leaf area (LA), fresh corm mass (FCM), root fresh weight (RFM), and root dry mass (RDM) were determined at 18,32 , and 40 weeks. LA was determined using a portable leaf area meter (Cl-202 portable Laser Leaf Area Meter; CID Bio-Science Inc., Camas, WA). CHL was measured at harvest using a portable non-destructive chlorophyll meter (CCM-2000; Opti-Sciences Inc., Hudson, NH) (Sedibe, 2020). The masses of fresh and dry roots, and corms were measured using a laboratory scale (Denver Instrument APX-602, Bohemia, NY). The roots and corms were washed immediately under running tap water while still attached to the mother plants. For each plant, the roots were counted and then detached from the corm for weighing. The corm was also detached from the plant afterward and weighed. All measurements for each plant took $\approx 5 \mathrm{~min}$. Harvested materials were oven dried before dry mass and the mineral content measurements.

Mineral analysis. Plant material obtained from the corms and leaves was oven dried at $60^{\circ} \mathrm{C}$ for $72 \mathrm{~h}$ after mineral analysis (Singh and Praharaj, 2017). Leaf and corm K, Ca, $\mathrm{P}, \mathrm{Mg}, \mathrm{Fe}, \mathrm{Zn}, \mathrm{Mn}, \mathrm{B}$, and $\mathrm{Cu}$ were determined using atomic emission spectrometry with inductive coupled plasma optical emission spectrometry (ICP-OES) (Optima 4300 DV ICP-OES; PerkinElmer Inc., Waltham, MA). The Dumas combustion method was used for total nitrogen determination in a Leco FP-528 combustion nitrogen analyzer (LecoCorp, St. Joseph, MO). Plant sulfur was determined by ICP-OES using an extract solution (Horiba Jobin Yvon, Ultima, Edison, NJ) (Sedibe and Allemann, 2012). Mo was determined by the calorimetric method after digesting samples with 


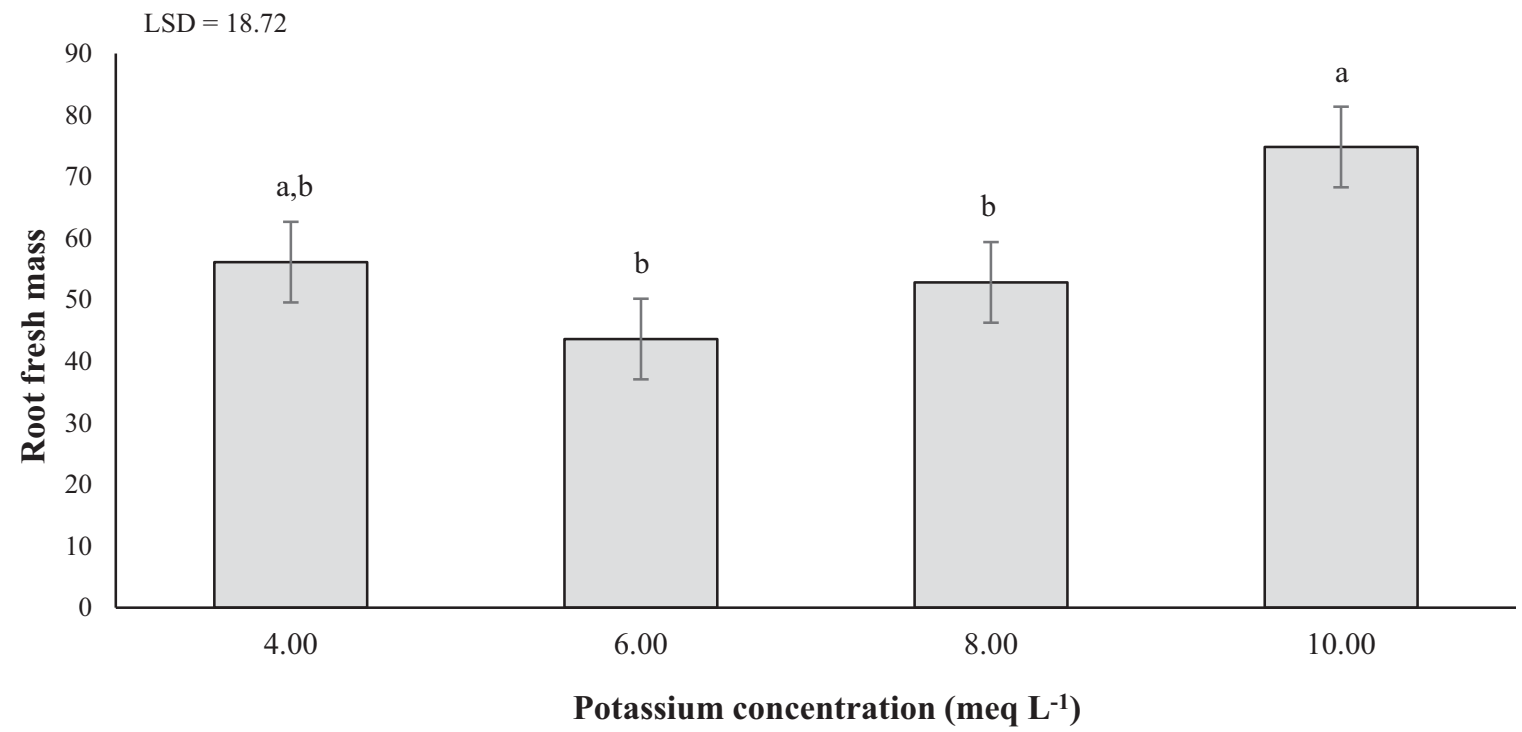

Fig. 2. Effects of potassium $\left(4.00,6.00,8.00\right.$, and $\left.10 \mathrm{meq} \cdot \mathrm{L}^{-1}\right)$ on root fresh weight of African potato collected 40 weeks after transplanting. Standard error (SE) is shown on the bar chart, the same letter on the bar charts denotes nonsignificance $(P<0.05)$, replications per treatment, $\mathrm{n}=6$.

$\mathrm{HNO}_{3}$ and $\mathrm{HCLO}_{4}$ (Singh and Praharaj, 2017).

Primary metabolite analysis. Only the corms were used to determine primary metabolites. The corm samples were prepared using the method described by Nsibande et al. (2018). Primary metabolites were determined using the ultra high-performance liquid chromatography (UHPLC)-mass spectrometry analysis method described by Mncwangi et al. (2014). The UHPLC analysis was performed on a Waters Acquity UHPLC system with photodiode array detection (Waters, Milford, MA).

Statistical analysis. Analysis of variance was conducted using statistical analysis software program (SAS Institute Inc., 2017) with the general linear model procedure. The Tukey's Student range test was used to separate means that were significantly different, at a $P$ value of 0.05 , as described by Steel and Torrie (1980). A principal component analysis (PCA) was done using XLSTAT 2015.04.36025 statistical software.

\section{Results}

Agronomic attributes. Different concentrations of $\mathrm{K}$ had significant effects on agronomic attributes after the first harvest (Table 3). $\mathrm{CHL}_{2}, \mathrm{LA}_{2}$, and $\mathrm{FCM}_{2}$ were significantly affected by $\mathrm{K}$ application at $10.00 \mathrm{meq} \cdot \mathrm{L}^{-1}$ $(P<0.05)$. $\mathrm{CHL}_{2}$ was significantly higher in plants grown at $10.00 \mathrm{meq} \cdot \mathrm{L}^{-1} \mathrm{~K}(28.51 \pm$
7.10) than plants at $6.00 \mathrm{meq} \cdot \mathrm{L}^{-1} \mathrm{~K}(13.10 \pm$ $12.18)$ and $4.00 \mathrm{meq} \cdot \mathrm{L}^{-1} \mathrm{~K}(16.21 \pm 11.33)$. $\mathrm{LA}_{2}$ and $\mathrm{FCM}_{2}$ were also increased in plants grown in $10.00 \mathrm{meq} \cdot \mathrm{L}^{-1} \mathrm{~K}(87.59 \pm 19.21$ and $57.13 \pm 14.52$, respectively) compared with those grown in $6.00 \mathrm{meq} \cdot \mathrm{L}^{-1} \mathrm{~K}(39.15$ \pm 27.79 and $34.91 \pm 10.53$, respectively).

For the third stage of data collection (40 weeks) only fresh corm mass $\left(\mathrm{FCM}_{3}\right)$, number of roots $\left(\mathrm{NR}_{3}\right)$, root fresh weight $\left(\mathrm{RFM}_{3}\right)$, and root dry mass $\left(\mathrm{RDM}_{3}\right)$ were measured because plants were experiencing dieback during the winter months (June-August). Out of these agronomic attributes, only $\mathrm{RFM}_{3}$ and $\mathrm{RDM}_{3}$ were significantly affected by $\mathrm{K}$ levels $(P<0.05)$ (Figs. 2 and 3$)$. The highest $\mathrm{RFM}_{3}(74.82 \pm 24.12)$ was at $10.00 \mathrm{meq} \cdot \mathrm{L}^{-1}$

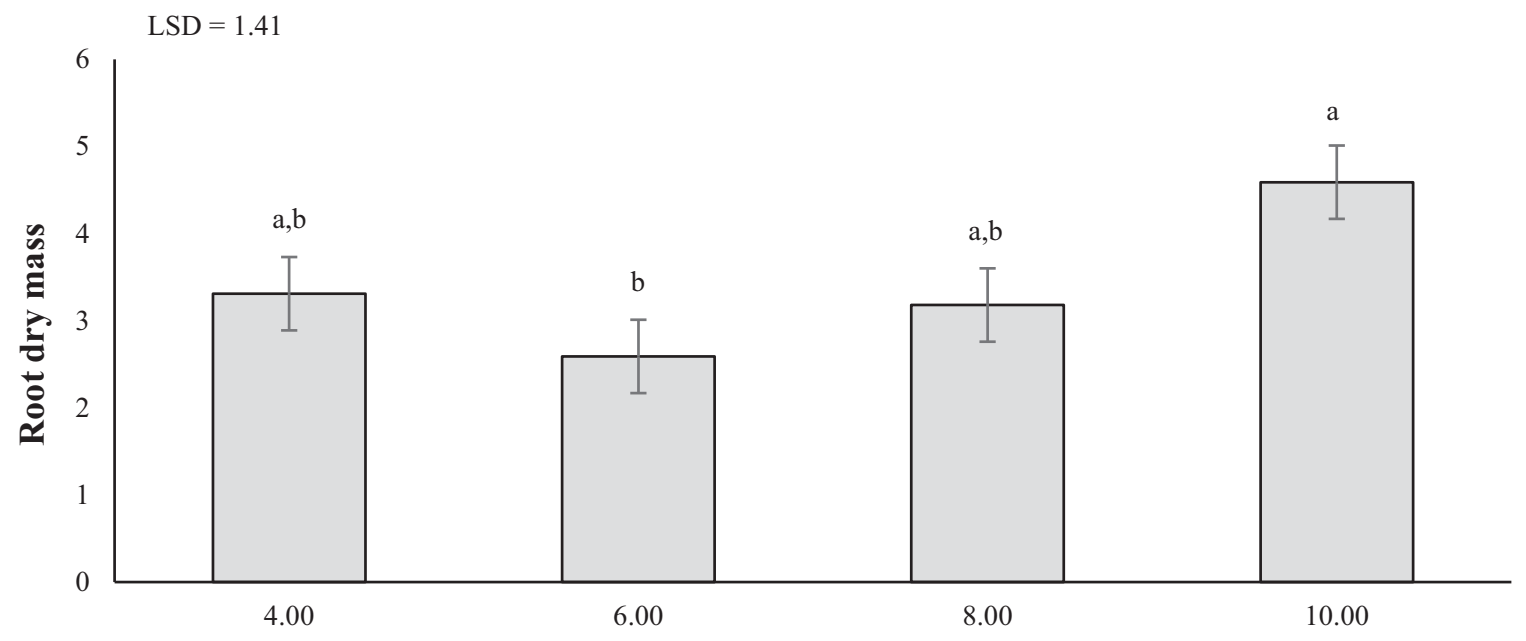

Potassium concentration (meq $\left.\mathrm{L}^{-1}\right)$

Fig. 3. Effects of potassium $\left(4.00,6.00,8.00\right.$, and $\left.10 \mathrm{meq} \cdot \mathrm{L}^{-1}\right)$ on root dry mass of African potato collected 40 weeks after transplanting. Standard error (SE) is shown on the bar chart, the same letter on the bar charts denotes nonsignificance $(P<0.05)$, replications per treatment, $\mathrm{n}=6$. 


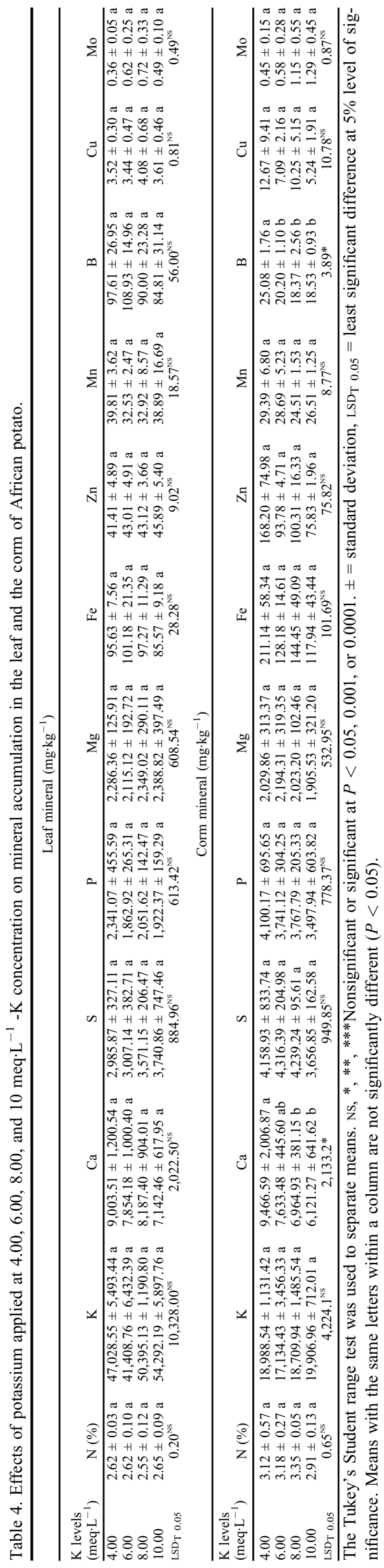

$\mathrm{K}$, which was not significantly higher than plants grown using a nutrient solution containing $4.00 \mathrm{meq} \cdot \mathrm{L}^{-1} \mathrm{~K}(56.12 \pm 25.04)$. There were no significant differences between $4.00,6.00$, and $8.00 \mathrm{meq} \cdot \mathrm{L}^{-1} \mathrm{~K}$. $\mathrm{RDM}_{3}$ of the $10.00 \mathrm{meq} \cdot \mathrm{L}^{-1} \mathrm{~K}$ treated plants was highest $(4.59 \pm 1.78)$, but was not significantly different from the $\mathrm{RDM}_{3}$ of plants grown in $4.00(3.31 \pm 1.59)$ and $8.00(3.18 \pm$ 1.41) $\mathrm{meq} \cdot \mathrm{L}^{-1} \mathrm{~K}$. The $\mathrm{RDM}_{3}$ was significantly lower $(P<0.05)$ at $6.00 \mathrm{meq} \cdot \mathrm{L}^{-1}$ $(2.59 \pm 1.63)$ compared with $10.00 \mathrm{meq} \cdot \mathrm{L}^{-1}$ $\mathrm{K}$. Although the same trends were not found in the other measured traits, plants grown in $10.00 \mathrm{meq} \cdot \mathrm{L}^{-1}$ produced the highest LA, FCM, RFM, and RDM values.

Mineral accumulation in the leaf and corm. The leaf and corm mineral contents from African potato are shown in Table 4. Apart from $\mathrm{Ca}$ and $\mathrm{B}$ in the corm, there was no significant effect of $\mathrm{K}$ concentration on leaf mineral concentration for the rest of the target minerals. Ca concentration in the corm was significantly higher $(P<0.05)$ when a low level $\left(4.00 \mathrm{meq} \cdot \mathrm{L}^{-1} \mathrm{~K}\right)$ nutrient solution was applied, compared with $\mathrm{Ca}$ levels obtained at 8.00 and $10.00 \mathrm{meq} \cdot \mathrm{L}^{-1}$, but did not differ significantly from $\mathrm{K}$ levels of $6.00 \mathrm{meq} \cdot \mathrm{L}^{-1}$. Similarly, a significantly high $(P<0.05)$ B content was also measured in plants grown in $4.00 \mathrm{meq} \cdot \mathrm{L}^{-1}$ $\mathrm{K}$ nutrient solution, however, no significant differences occurred at $6.00,8.00$, or 10.00 meq $\cdot \mathrm{L}^{-1} \mathrm{~K}$.

Primary metabolites. Only alanine and malic acid metabolites were significantly $(P$ $<0.05$ ) affected by the concentration of $\mathrm{K}$, as shown in Figs. 4 and 5. Alanine was highest at $10.00 \mathrm{meq} \cdot \mathrm{L}^{-1}$; however, malic acid decreased with increased levels of $\mathrm{K}$ in the nutrient solution from $4.00 \mathrm{meq} \cdot \mathrm{L}^{-1} \mathrm{~K}$ until $8.00 \mathrm{meq} \cdot \mathrm{L}^{-1} \mathrm{~K}$, where a 4437261 peak area was recorded.

Principal component analysis. In the PCA, most measured agronomic attributes were loaded positively on PC1 (Fig. 6). PC1 accounted for $55.17 \%$, whereas $\mathrm{PC} 2$ accounted for $12.84 \%$ of the variation. $\mathrm{K}$ concentrations of $4.00,8.00$, and $10.00 \mathrm{meq} \cdot \mathrm{L}^{-1}$ positively loaded most agronomic attributes together.

A very weak negative correlation occurred between $\mathrm{K}$ and $\mathrm{Ca}$ in both the leaf $\left(r^{2}=-0.39\right)$ and corm $\left(r^{2}=-0.26\right) . \mathrm{K}$ and $\mathrm{B}$ had a strong negative association in the leaf $\left(r^{2}=-0.99\right)$, although no relationship existed between $\mathrm{K}$ and $\mathrm{B}$ in the corm $\left(r^{2}=-0.05\right)$. Two principal components explained the total variation of $80.36 \%$ in mineral accumulation (Fig. 7). PC1 accounted for $51.70 \%$, and PC2 accounted for $28.65 \%$. The $\mathrm{K}$ level of 4.00 meq $\mathrm{L}^{-1}$ positively loaded corm $\mathrm{B}, \mathrm{P}, \mathrm{Fe}, \mathrm{Zn}$, $\mathrm{Ca}, \mathrm{Cu}$, and $\mathrm{Mn}$, as well as leaf $\mathrm{P}$ and $\mathrm{Ca}$ together in one cluster on PC2. Corm K, followed by leaf $\mathrm{K}, \mathrm{Mg}, \mathrm{Mn}, \mathrm{N}$, and $\mathrm{S}$ were loaded positively on PC1 when 10.00 meq. $\mathrm{L}^{-1}$ of $\mathrm{K}$ was used in the nutrient solution.

The PCA showed that most primary metabolites positively loaded on PC1, except carnitine, glycine, and creatinine, which loaded negatively on both PC1 and PC2 (Fig. 8). The total percentage of both PCs was only $36.55 \%$, with PC1 accounting for $21.70 \%$ and PC2 accounting for $14.85 \%$ of the total variation. Most primary metabolites loaded positively at all the applied $\mathrm{K}$ concentrations.

\section{Discussion}

The concentration of $\mathrm{K}$ had a significant effect on agronomic attributes, mineral accumulation, and primary metabolite synthesis in African potato plants. The increased CHL, LA, FCM, RFM, and RDM observed at $10.00 \mathrm{meq} \cdot \mathrm{L}^{-1} \mathrm{~K}$ might be attributed to enhanced enzyme activity, as $\mathrm{K}$ is known to activate enzymes in plant metabolism (Chrysargyris et al., 2017; Koch et al., 2019). Increased CHL content at $4.00 \mathrm{meq} \cdot \mathrm{L}^{-1} \mathrm{~K}$, and the consequent increase in other agronomic attributes despite the low $\mathrm{K}$ levels, might be due to the higher levels of $\mathrm{Ca}$ and $\mathrm{Mg}$, which are also involved in cell growth and enzyme activation (Jones, 2012; Mugundhan et al., 2011).

$\mathrm{K}$ and $\mathrm{Ca}$ have a strong antagonistic relationship (Nguyen et al., 2017); however, in this study, no significant antagonistic relationship between $\mathrm{K}$ and $\mathrm{Ca}$ was found. Increased $\mathrm{Ca}$ and $\mathrm{B}$ accumulation in the corm at the lowest $\mathrm{K}$ concentration might be due to the genetic ability of African potato to accumulate nutrients in the corm, even at low soil fertility levels (McAlister and van Staden, 1995).

Primary metabolites are vital for growth, development, and the response to environmental pressures (Hong et al., 2016; Khan et al., 2020). Secondary metabolites are biosynthetically produced from primary metabolites (Kumar and Rajesh, 2018). In the current study, alanine increased with higher $\mathrm{K}$ concentrations in the nutrient solution. This result concurs with the results of Ibrahim et al. (2012) that have indicated that increasing $\mathrm{K}$ increased the production of soluble protein and phenylalanine ammonialyase activity in Labisia pumila. Therefore, increasing $\mathrm{K}$, and the corresponding increase in alanine production, could promote useful secondary metabolite synthesis in African potato. Malic acid acts as a counter ion for $\mathrm{K}$ and $\mathrm{Ca}$ cations, particularly in nitrate-dependent plants (Ghazijahani et al., 2018). The rise in $\mathrm{Ca}$ at 4.00 meq. $\mathrm{L}^{-1} \mathrm{~K}$ increased malic acid synthesis, however, increasing $\mathrm{K}$ up to $8.00 \mathrm{meq} \cdot \mathrm{L}^{-1} \mathrm{~K}$ decreased malic acid production. This trend in malic acid synthesis was erratic and inconsistent, which might be due to the combined effects of nutrient imbalances and other environmental conditions that were not tested.

Most agronomic attributes were loaded positively on $\mathrm{PC} 1$, with most clustering together at $\mathrm{K}$ levels of $4.00,8.00$, and 10.00 meq $\cdot \mathrm{L}^{-1}$. The PCA grouped certain minerals according to the $\mathrm{K}$ levels. Leaf $\mathrm{P}$ and $\mathrm{Ca}$ along with corm $\mathrm{B}, \mathrm{P}, \mathrm{Fe}, \mathrm{Zn}, \mathrm{Ca}, \mathrm{Cu}$, and Mn clustered positively at $4.00 \mathrm{meq} \cdot \mathrm{L}^{-1} \mathrm{~K}$. On the other hand, corm $\mathrm{K}$ in addition to leaf $\mathrm{K}, \mathrm{Mg}, \mathrm{Mn}, \mathrm{N}$, and S were attributed to 10.00 $\mathrm{meq} \cdot \mathrm{L}^{-1} \mathrm{~K}$ on $\mathrm{PC} 1$. Because the corm is harvested and used for medicinal purpose, 


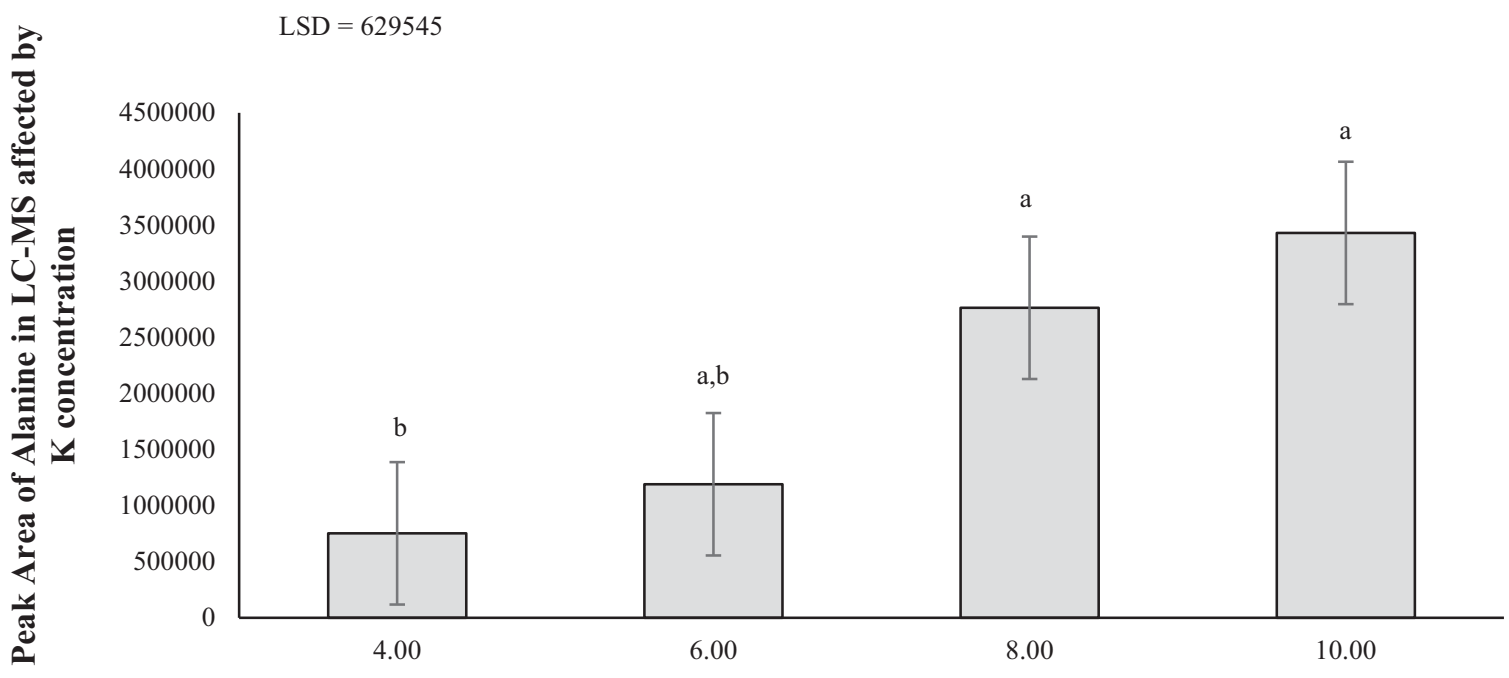

\section{Potassium concentration (meq $\left.\mathrm{L}^{-1}\right)$}

Fig. 4. The peak area of alanine in liquid chromatography-mass spectrometry of African potato plants fertigated using potassium (4.00, 6.00, 8.00 , and 10 meq $\cdot \mathrm{L}^{-1}$ ) nutrient solution. The Tukey's Student range test was used to separate means. Standard error (SE) is shown on the bar chart, the same letter on the bar charts denotes non significance $(P<0.05)$, replications per treatment, $\mathrm{n}=6$.

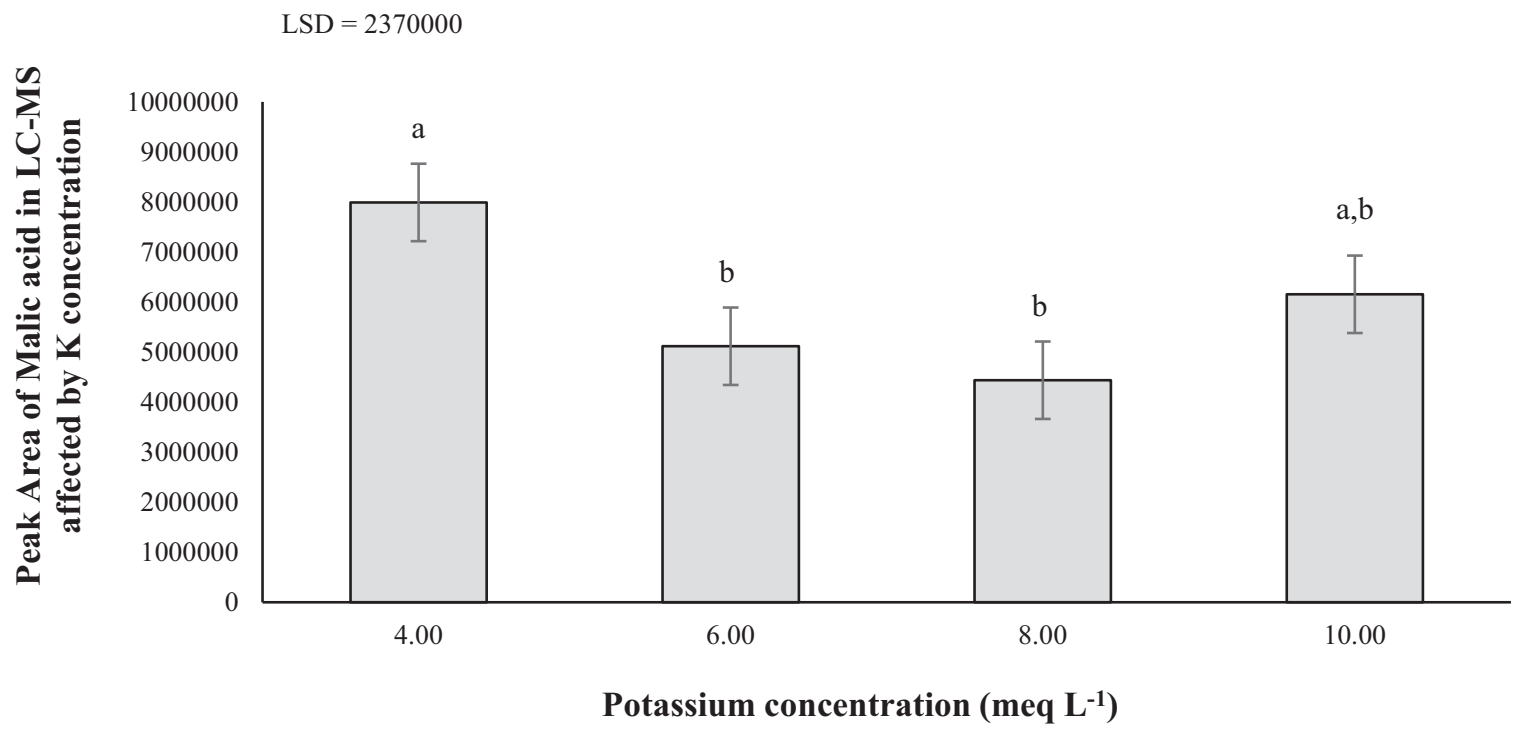

Fig. 5. The peak area of malic acid in liquid chromatography-mass spectrometry of African potato fertigated using potassium (4.00, 6.00, 8.00 , and 10 meq $\cdot \mathrm{L}^{-1}$ ) nutrient solution. The Tukey's student range test was used to separate means. Standard error (SE) is shown on the bar chart, the same letter on the bar charts denotes nonsignificance $(P<0.05)$, replications per treatment, $\mathrm{n}=6$.

nutrient solutions with $4.00 \mathrm{meq} \cdot \mathrm{L}^{-1} \mathrm{~K}$ could be recommended for fertigating African potato. All $\mathrm{K}$ levels used in this study had a positive effect on primary metabolite synthesis, which could positively affect secondary metabolism in these plants (Kumar and Rajesh, 2018).

\section{Conclusion}

These results show that the successful cultivation of African potato could be achieved through nutrient management in a temperature-controlled greenhouse. This study revealed that a high $\mathrm{K}$ nutrient solution is needed to improve all the measured agronomic traits, but this did not affect the leaf mineral content. $\mathrm{K}$ nutrient solution affected some mineral and primary metabolite components of the corm; therefore, plant parts that are important for medicinal purposes should be investigated further. Since the corm is harvested and used for medicinal purposes, a nutrient solution with $4.00 \mathrm{meq} \cdot \mathrm{L}^{-1} \mathrm{~K}$ can be recommended to fertigate African potato because this solution accumulates micronutrients in the corm. Primary metabolite synthesis of African potato at a low $\mathrm{K}$ level of 4.00 meq $\cdot \mathrm{L}^{-1}$ might yield useful secondary metabolites responsible for the medicinal properties of African potato. A further secondary metabolite analysis should be conducted to ascertain the right $\mathrm{K}$ level for growing African potato of high medicinal quality. It may be beneficial to determine $\mathrm{K}$ content of the growth media before planting in future studies because some growth media may contain traces of $\mathrm{K}$. 
Biplot (axes PC1 and PC2: 68.02\%)

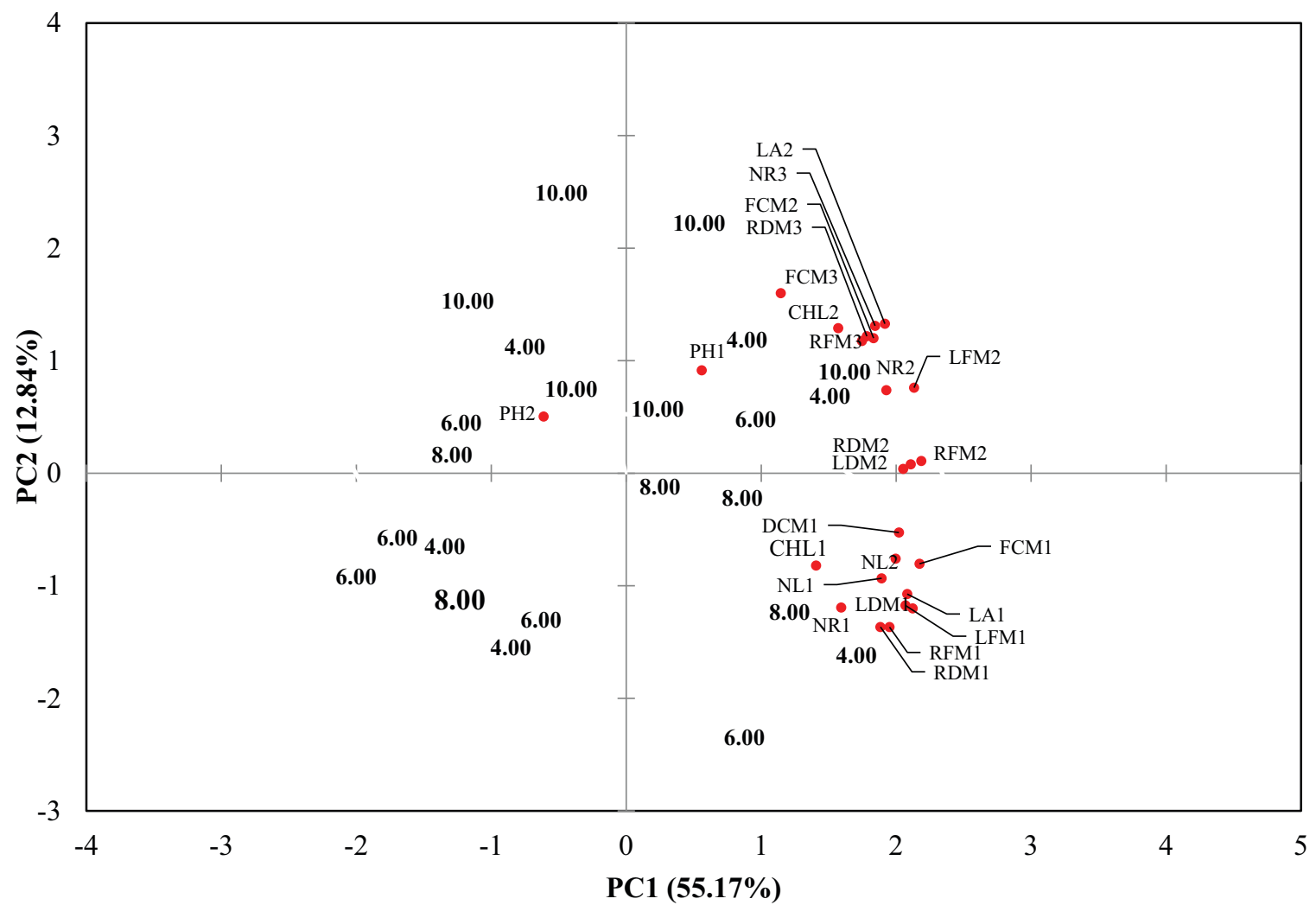

Fig. 6. Rotated principal component loadings of agronomic attributes of African potato grown using potassium applied at $4.00,6.00,8.00$, and $10 \mathrm{meq} \cdot \mathrm{L}^{-1} \mathrm{~K}$ concentration. $\mathrm{CHL}=$ chlorophyll content; $\mathrm{LA}=$ leaf area $\left(\mathrm{cm}^{2}\right) ; \mathrm{PH}=$ plant height $(\mathrm{cm}) ; \mathrm{FCM}=$ fresh weight of corms $(\mathrm{g}) ; \mathrm{DCM}=$ dry mass of the corms (g); NR = number of roots; RFM = root fresh weight (g); RDM = root dry mass $(\mathrm{g}) ; \mathrm{NL}=$ number of leaves per plant; LFM = leaf fresh weight (g); LDM = leaf dry mass (g); 1, 2, and 3 represent the first, second, and third data collections, respectively.

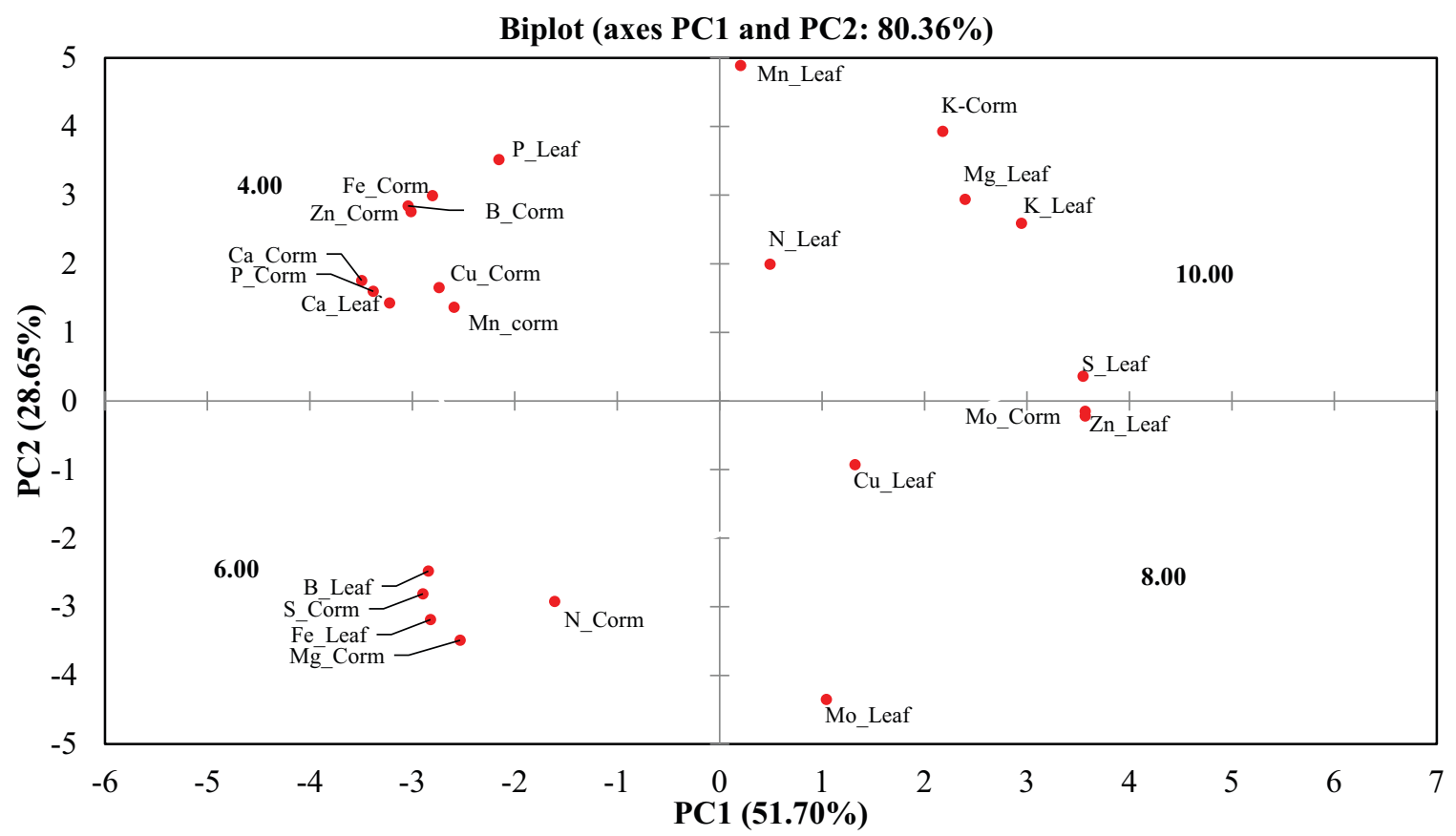

Fig. 7. Rotated principal component loadings of mineral accumulation in the leaf and corm of African potato grown using potassium applied at $4.00,6.00$, 8.00 , and $10 \mathrm{meq} \cdot \mathrm{L}^{-1}-\mathrm{K}$ concentration. 
Biplot (axes PC1 and PC2: 36.55\%)

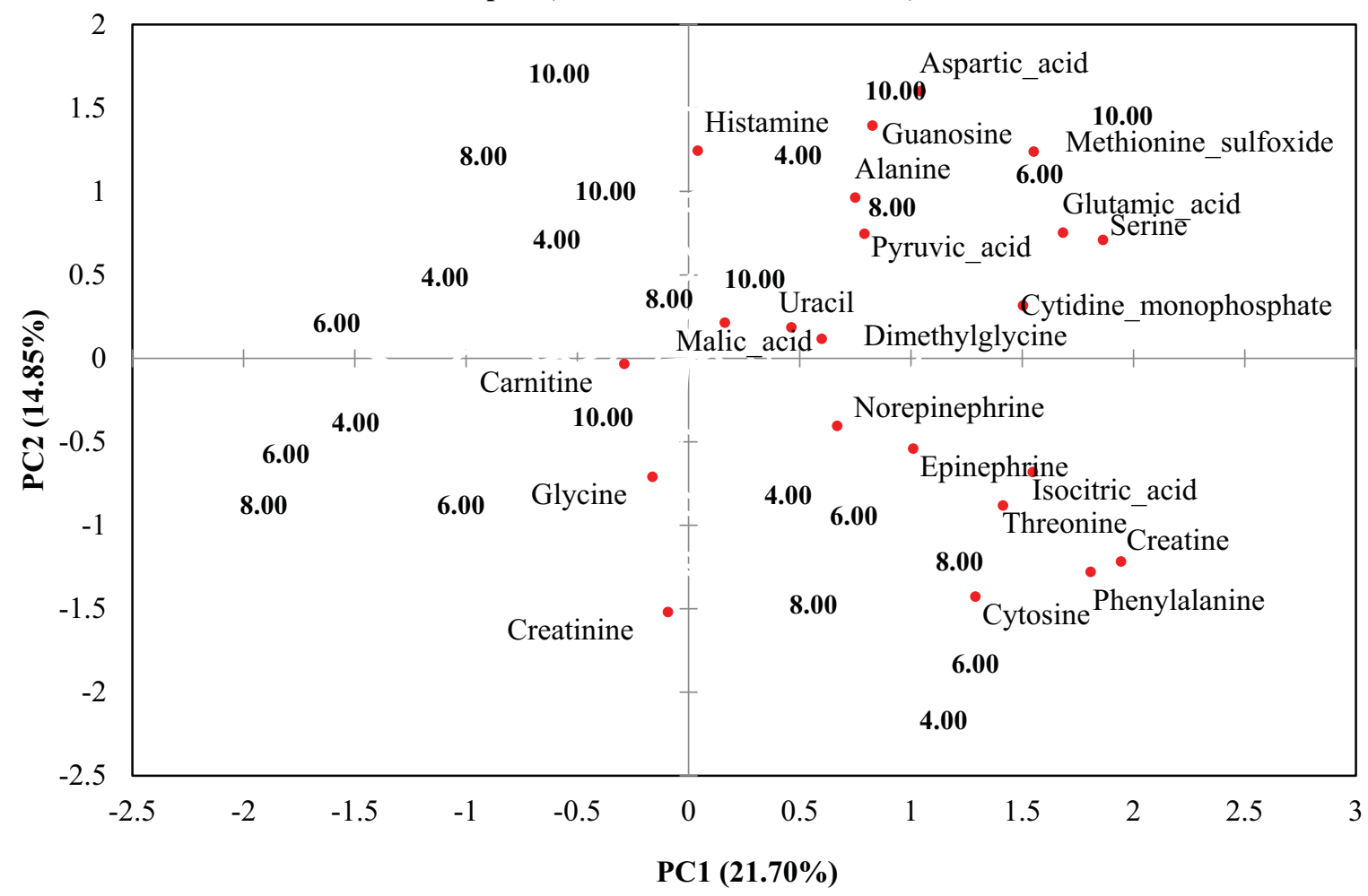

Fig. 8. Rotated principal component loadings of primary metabolites of African potato grown using potassium applied at $4.00,6.00,8.00$, and 10 meq $\cdot \mathrm{L}^{-1}$ $-\mathrm{K}$ concentration.

\section{Literature Cited}

Ávila-Juárez, L., I. Torres-Pacheco, R.V. OcampoVelázquez, A.A. Feregrino-Pérez, A. Cruzhernández, and R.G. Guevara-González. 2017. Integrating plant nutrients and elicitors for production of secondary metabolites, sustainable crop production and human health: A review. Intl. J. Agr. Biol. 19:391-402, https://doi.org/ 10.17957/ijab/15.0297.

Chen, S.L., H. Yu, H.M. Luo, Q. Wu, C.F. Li, and A. Steinmetz. 2016. Conservation and sustainable use of medicinal plants: Problems, progress, and prospects. Chin. Med. J. 11:1-10, https://doi. org/10.1186/s13020-016-0108-7.

Chrysargyris, A., P. Xylia, G. Botsaris, and N. Tzortzakis. 2017. Antioxidant and antibacterial activities, mineral and essential oil composition of spearmint (Mentha spicata L.) affected by the potassium levels. Ind. Crops Prod. 103:202-212, https://doi.org/10.1016/j.indcrop. 2017.04.010.

Combrink, N.J.J. 2019. Nutrient solution management. Department of Agronomy, Stellenbosch University, RSA.

Ghazijahani, N., E. Hadavi, M.S. Son, and B.R. Jeong. 2018. Foliar application of citric and malic acid to stock plants of rose alters the rooting of stem cuttings. Chem. Biol. Technol. Agric. 5:1-6, https://doi.org/10.1186/s40538-018-0123-2.

Hasanuzzaman, M., M.H.M.B. Bhuyan, K. Nahar, M.S. Hossain, J.A. Mahmud, M.S. Hossen, A.A.C. Masud, Moumita, and M. Fujita. 2018. Potassium: A vital regulator of plant responses and tolerance to abiotic stresses. Agronomy 8:1-29, https://doi.org/10.3390/agronomy8030031.

Hong, J., L. Yang, D. Zhang, and J. Shi. 2016. Plant metabolomics: An indispensable system biology tool for plant science. Intl. J. Mol. Sci. 17:1-16, https://doi.org/10.3390/ijms17060767.

Ibrahim, M., H. Jaafar, E. Karimi, and A. Ghasemzadeh. 2012. Primary, secondary metabolites, photosynthetic capacity and antioxidant activity of the Malaysian herb kacip fatimah (Labisia Pumila Benth) exposed to potassium fertilization under greenhouse conditions. Intl. J. Mol. Sci. 13:15321-15342, https://doi.org/10.3390/ ijms131115321.

Jackson, B.E. and R.D. Wright. 2009. Changes in chemical and physical properties of pine tree substrate and pine bark during long-term nursery crop production. HortScience 44:3, https:// doi.org/10.21273/HORTSCI.44.3.791.

Jones, J.B. 2012. Plant nutrition and soil fertility manual. 2nd ed. CRC Press, Taylor and Francis Group, New York.

Kalaji, H.M., W. Bąba, K. Gediga, V. Goltsev, I.A Samborska, M.D. Cetner, S. Dimitrova, U. Piszcz, K. Bielecki, K. Karmowska, K. Dankov, and A. Kompała-Bąba. 2017. Chlorophyll fluorescence as a tool for nutrient status identification in rapeseed plants. Photosyn. Res. 136:329-343, https:// doi.org/10.1007/s11120-017-0467-7.

Khan, N., S. Ali, P. Zandi, A. Mehmood, S. Ullah, M.I. Ismail, M.A. Shahid, and M.A. Babar. 2020. Role of sugars, amino acids and organic acids in improving plant abiotic stress tolerance. Pakistan J. Bot. 52:1-9, https://doi.org/ 10.30848/PJB2020-2(24).

Khetsha, Z.P. and M.M. Sedibe. 2015. Effect of potassium and potting-bag size on foliar biomass and related attributes and oil composition of rose geranium (Pelargonium graveolens). S. Afr. J. Plant Soil 32:1-3, https://doi.org/ 10.1080/02571862.2014.994143
Koch, M., M. Busse, M. Naumann, B. Jákli, I. Smit, I. Cakmak, C. Hermans, and E. Pawelzik. 2019. Differential effects of varied potassium and magnesium nutrition on production and partitioning of photo assimilates in potato plants. Physiol. Plant 166:921-935, https://doi. org/10.1111/ppl.12846.

Kumar, I. and K.S. Rajesh. 2018. Production of secondary metabolites in plants under abiotic stress: An overview. Signif. Bioeng. Biosci. 2:196-200, https://doi.org/10.31031/SBB.2018.02.000545.

Kumar, V., M. Moyo, and J. van Staden. 2016. Somatic embryogenesis in Hypoxis hemerocallidea: An important African medicinal plant. S Afr. J. Bot. 108:331-336, https://doi.org/10.10 16/j.sajb.2016.08.012.

McAlister, B.G. and J. van Staden. 1995. Effect of artificially induced stress conditions on the growth of the medicinal plant Hypoxis hemerocallidea. S. Afr. J. Bot. 61:85-89, https://doi. org/10.1016/j.sajb.2016.08.012.

Mncwangi, N.P., A.M. Viljoen, J. Zhao, I. Vermaak, W. Chen, and I. Khan. 2014. What the devil is in your phytomedicine? Exploring species substitution in Harpagophytum through chemometric modeling of 1 H-NMR and UHPLC-MS datasets. Phytochemistry 106:104-115, https://doi. org/10.1016/j.phytochem.2014.06.012.

Mofokeng, M.M., H.T. Araya, S.O. Amoo, D. Sehlola, C.P. du Plooy, M.W. Bairu, S. Venter, and P.W. Mashela. 2020. Diversity and conservation through cultivation of Hypoxis in Africa-A case study of Hypoxis hemerocallidea. Diversity 12:1-23, https://doi.org/10.3390/d12040122.

Mugundhan, R.M., M. Soundaria, V. Maheswari, P. Santhakumari, and V. Gopal. 2011. "Hydroponics"- A novel alternative for geoponic 
cultivation of medicinal plants and food crops. Intl. J. Pharma. Bio. Sci. 2:286-296.

Nguyen, H.H., S. Maneepong, and P. Suraninpong. 2017. Effects of potassium, calcium, and magnesium ratios in soil on their uptake and fruit quality of pummelo. J. Agricultural Sci. 9:110-121, https://doi.org/10.5539/jas.v9n12p110.

Nsibande, B.E., K.E. Gustavsson, and L.H. Zhu. 2018. Analysis of health-associated phytochemical compounds in seven Hypoxis species. Amer. J. Plant Sci. 9:571-583, https://doi.org/ 10.4236/ajps.2018.94044.

Nyakane, N.E., M.M. Sedibe, and E. Markus. 2019. Growth response of rose geranium
(Pelargonium graveolens L.) to calcium: Magnesium ratio, magnetic field, and mycorrhizae. HortScience 54:1762-1768, https://doi.org/ 10.21273/HORTSCI14248-19.

SAS Institute Inc. 2017. SAS/STAT 14.3 User's Guide. SAS Institute Inc., Cary, NC.

Sedibe, M.M. and J. Allemann. 2012. Yield and quality response of rose geranium (Pelargonium graveolens $\mathrm{L}$.) to sulphur and phosphorus application. S. Afr. J. Plant Soil 29:151-156, https://doi.org/10.1080/02571862.2012.744108.

Sedibe, M.M. 2020. The physiological and quality response of Pelargonium graveolens (L.) grown on nitrate and ammonium nutrient solutions.
Appl. Ecol. Environmental Res. 18:8081-8090, https://doi.org/10.15666/aeer/1806_80818090.

Singh, U. and C.S. Praharaj. 2017. Practical manual-chemical analysis of soil and plant samples. ICAR-Indian Institute of Pulses Research. Kanpur, Uttar Pradesh, India.

Steel, R.G.D. and J.H. Torrie. 1980. Principles and procedures of statistics: A biometrical approach 2nd ed. McGraw-Hill, New York, NY.

Verma, N. and S. Shukla. 2015. Impact of various factors responsible for fluctuation in plant secondary metabolites. J. Appl. Res. Medicinal Aromatic Plants 2:105-113, https://doi.org/10.1016/j. jarmap.2015.09.002. 